\title{
Larvae occurrences of Rhamdia quelen (Quoy \& Gaimard, 1824) (Siluriformes: Heptapteridae) in an area under dam influence in the upper Paraná River region, Brazil
}

\author{
Evelyn B. da Silva ${ }^{1}$, Pablo H. dos Santos Picapedra ${ }^{1}$, Paulo V. Sanches ${ }^{2,4}$, \\ Renato E. O. de Rezende ${ }^{3}$, Aline M. Gavião ${ }^{3}$, Marcos M. Mendonça ${ }^{4}$, \\ Edilaine D. V. Gonçalves ${ }^{3}$ and Rafael Bier Conte $^{5}$
}

Rhamdia quelen (Jundiá) is a catfish species of great interest to fish producers and researchers due to several favorable characteristics for inclusion in the Brazilian list of commercially raised fish. It has a wide geographical distribution, with occurrences reported from Central Argentina to South Mexico. Studies on the biological aspects of this species have been limited to captive adult fishes that were researched for farming purposes. Research related to ichthyoplankton has provided valuable information on spawning periods and sites and other aspects of breeding for numerous species of fish. This information is crucial for implementing management and protection strategies for these species. The studied floodplain is located in a lotic remnant between the Reservoirs of Itaipu and Engenheiro Sérgio Motta. This area is located inside a protected area (Ilha Grande National Park) in the last portion of dam-free land along the Paraná River in the Brazilian territory; however, it is still threatened by the negative effects of the dams. We conducted monthly nocturnal collections during four periods from October to March, 2003 to 2007, in 22 locations along the main channel, secondary lakes and main tributaries of the Paraná River. After collection, the individuals were classified according to the degree of development and the notochord flexion and caudal fin support elements. Data were analyzed using principal component analysis (PCA), ANOVA and Pearson correlation to relate abiotic and larval density data. The increase of capture abundances in the four studied stages suggests that $R$. quelen is finding conditions that are favorable to its reproduction. The increase in captures can generate questions regarding $R$. quelen reproductive activity, for instance, whether the species is adapting or is influenced by environmental changes created by the Paraná River dams.

Rhamdia quelen (jundiá) é uma espécie de bagre que tem despertado grande interesse dos piscicultores e pesquisadores devido a várias características favoráveis a sua inclusão na lista de peixes criados comercialmente no país. Apresenta ampla distribuição geográfica, tendo sua ocorrência registrada desde a região central da Argentina até o sul do México, entretanto, os aspectos de sua biologia que foram estudados são em sua a maioria direcionada aos adultos e em cativeiro, com fins aquícolas. Pesquisas relacionadas ao ictioplâncton têm-se mostrado de grande importância por fornecer informações valiosas sobre a época, locais de desova e de criadouros naturais de várias espécies de peixes. Essas informações são fundamentais para a implementação de medidas de ordenamento e proteção dessas áreas. A planície de inundação estudada está localizada em um remanescente lótico, entre os reservatórios de Itaipu e Engenheiro Sérgio Motta. Apesar da unidade de conservação existente nesse trecho (Parque Nacional de Ilha Grande) e de estar localizada no último trecho livre de barramentos do rio Paraná em território brasileiro, a área é especialmente impactada pelos efeitos negativos dos barramentos. Foram realizadas coletas mensais noturnas durante quatro

\footnotetext{
'Programa de Pós-Graduação em Biologia Comparada (PGB), Universidade Estadual de Maringá (UEM). Av. Colombo, 5790, 87020-900 Maringá, Paraná, Brazil. evelyn.barzotto@hotmail.com (EBS), pablo_picapedra@hotmail.com (PHP).

${ }^{2}$ Centro de Ciências Exatas e Engenharias, Universidade Estadual do Oeste do Paraná (UNIOESTE). Rua da Faculdade, 645, 85903-000 Jardim La Salle Toledo, Paraná, Brazil. pvsanches@yahoo.com.br (PVS).

${ }^{3}$ Universidade Paranaense (UNIPAR). Av. Parigot de Souza, 3636, 85903-170 Toledo, Paraná, Brazil. renatoreor@gmail.com (REOR), alinegaviao@gmail.com (AMG), biodi@hotmail.com(EDVG).

${ }^{4}$ Programa de Pós-Graduação em Recursos Pesqueiros e Engenharia de Pesca (PREP), Universidade Estadual do Oeste do Paraná (UNIOESTE). Rua da Faculdade, 645, 85903-000 Jardim La Salle, Toledo, Paraná, Brazil. marcos-1811@hotmail.com (MMM).

${ }^{5}$ Programa de Pós-Graduação em Biotecnologia Aplicada a Agricultura (PBAA), Universidade Paranaense (UNIPAR). Praça Mascarenhas de Moraes, 4282, 87502-210 Umuarama, Paraná, Brazil. rafa_bconte@hotmail.com (RBC).
} 
etapas entre os meses de outubro a março dos anos de 2003 a 2007 em 22 estações no leito principal do rio Paraná, lagoas marginais e principais afluentes. Após as triagens, as larvas foram classificadas de acordo com o grau de flexão da notocorda e desenvolvimento dos elementos de suporte da nadadeira caudal. Os dados foram submetidos à Análise de Componentes Principais (ACP), Análise de Variância e correlação de Pearson para sumarizar os dados abióticos e as densidades de larvas. O aumento da abundância de captura, nas quatro fases estudadas sugere que $R$. quelen tem encontrado condições favoráveis à sua reprodução. $\mathrm{O}$ aumento na captura pode gerar dúvidas sobre a atividade reprodutiva de $R$. quelen, por exemplo, se a espécie se adapta ou é influenciada por alterações no ambiente criado pelas barragens do rio Paraná.

Key words: Ichthyoplankton, Ilha Grande National Park, Jundiá, Spawning areas.

\section{Introduction}

Popularly known in Brazil as jundiá or frog catfish, Rhamdia quelen (Quoy \& Gaimard, 1824) can reach up to 50 $\mathrm{cm}$ in total length and weigh up to $3 \mathrm{~kg}$. This species prefers calmer and deeper water along banks and vegetation with a sand or mud bottom. It hides among stones and rotten trunks during the day and leaves these hiding places at night to forage (Guedes, 1980). This species is of interest to producers and researchers because of several characteristics that favor its inclusion in the Brazilian list of commercially raised fish (Gomes et al., 2000; Carneiro et al., 2003). According to the fishery statistics in Ibama (2007), in 2005, jundiá was the second most caught fish in artisanal fisheries (395.0 tons/ year), and the third most produced by continental freshwater aquiculture (358.0 tons/year) in southern Brazil. Thus, it is very important to fish farming, particularly in southern Brazil (Gomes et al., 2000; Carneiro et al., 2003).

Jundiá is distributed from Argentina to southern Mexico (Gomes et al., 2000). In Brazil, it is found in the main River basins, such as the Uruguay, Paraná/Paraguay, São Francisco and the Amazon basins (Agostinho et al., 2007). Despite the large distribution of this species, studies on the biological aspects of this species have been primarily conducted on captive adult fish for farming purposes. Therefore, this study is relevant because of the lack of data on the reproductive dynamics and developmental stages of this species in its natural environment. There is some debate regarding aspects of their reproductive habits; for instance, it is considered a great migratory species by Zaniboni-Filho \& Schulz (2004), but it is considered a non-migratory species or species of short-distance migration by Suzuki et al. (2004). Moreover, there are no data related to the possible influences of dams on the species reproduction.

The Paraná River is severely impacted by dams. Currently there are 146 large dams in the basin, 70\% was allocated to hydro generation (104). Importantly, many of them have an area exceeding $100 \mathrm{~km}^{2}$. The total area of wetland in the basin is approximately $16,700 \mathrm{~km}^{2}$, accounting for almost half the water impounded in the country. The contribution of hydropower to that flooding is almost complete (Agostinho et al., 2007). The most recent impact was caused by the activation of the Hydroelectric Power Plant Sérgio Motta (Porto Primavera), which drastically reduced the lotic area of the Paraná River (Sanches et al., 2006).
The floodplain is located in a lotic remnant between Itaipu and Engenheiro Sérgio Motta Reservoirs. This area is located inside a protected area (Ilha Grande National Park) in the last dam-free section of the Paraná River in the Brazilian territory; however, it is still threatened by the negative effects of the dams. Data on fish larvae occurrences have provided information on annual variation in reproduction from both natural and managed processes (Nakatani et al., 2001). This information is of fundamental importance to management and protection strategies aimed at maximizing recruitment and maintaining fish stocks in these areas (Baumgartner $e t$ al., 2004). To gain a better understanding of the environmental mechanisms that influence fish behavior, information on the relationships between larvae occurrences and environmental conditions in the spawning and developing areas is needed. This should include a survey on eggs and larvae in the Paraná River, especially as there is no study about the species larvae.

Therefore, the aim of this study is to determine monthly abundances of larvae and juveniles of $R$. quelen and possible spawning and developing sites along a free stretch of the Paraná River that is under the dams' influence. We examine the relationships between larval and juveniles abundances and environmental variables, thereby providing insight into the species' initial development in natural environments. Our results may help in managing this area as well as the preservation of spawning areas and growth of $R$. quelen.

\section{Material and Methods}

\section{Study area}

The study area is located on the Paraná River at the natural border between the States of Paraná and Mato Grosso do Sul. It is delimited upstream by the Sérgio Motta Hydroelectric Power Plant (Porto Primavera) dam and downstream by the Itaipu Hydroelectric Power Plant Reservoir.

The study region contains the Ilha Grande archipelago, which comprises a fluvial complex of roughly 157 islands of various sizes. The Ilha Grande National Park (IGNP) is located in the south region of upper Paraná River floodplain $\left(23^{\circ} 16^{\prime}\right.$ to $24^{\circ} 14^{\prime} \mathrm{S}$ and $53^{\circ} 43^{\prime}$ to $54^{\circ} 14^{\prime} \mathrm{W}$ ), its total area is 75,894 ha (Coripa, 2003). The archipelago's largest island, Ilha Grande, is approximately $80 \mathrm{~km}$ long and $5 \mathrm{~km}$ wide, and divides the Paraná River into two channels. 
The presence of several islands transforms the river into an anastomosed channel with different flow and depth characteristics, and includes backwater areas and shallow (roughly $2 \mathrm{~m}$ ) secondary channels with lower flow speeds as well as deep channels (over $12 \mathrm{~m}$ ) with strong rapids. Flooded areas are observed on both banks.

Although under influence of the dams, this stretch of the river has several tributaries that are dam-free: the Piquiri River located on the left bank of Paraná River (Paraná State) and the Amambaí and Iguatemi Rivers (Mato Grosso do Sul State) on the right bank. The flow characteristics of these tributaries exclusively depend on the hydrological cycle. In addition to these tributaries, the region contains several marginal lakes with a constant or intermittent connection to the Paraná River or secondary channels (Fig. 1). The left bank of the Paraná River has a higher declivity, resulting in a more restricted floodplain. This stretch contains high habitat heterogeneity with a high diversity of terrestrial and aquatic organisms (Agostinho et al., 2000; Agostinho et al., 2004b).

\section{Sampling}

Twenty-two sampling stations, twenty are lotic (Bandeirantes right channel; Amambaí;Triângulo; Porto Santo Antônio; Peruzzi; Paraná/Iguatemi; Iguatemi; Paraná/ Saraiva; Ilha Grande right channel; Bandeirantes left channel; Ilha Grande Pontal; Alvarenga; Esmeralda;Três Coqueiros; São João; Porto Luiz; Porto Cerâmica; Piquiri; Porto Terra Roxa; Ilha Grande left channel) and two are lentic (Saraiva middle e Saraiva channel), were located in the Paraná River's main stream bed, major tributaries, and marginal lakes throughout the entire area of Ilha Grande National Park (Fig. 1).

Samples were collected always in the evening from 2003 to 2007 during four spawning seasons, extending from October to March, as recommended by Vazzoler (1996). Period I was between October 2003 and March 2004; period II between October 2004 and March 2005; period III between October 2005 to March 2006; and period IV from October 2006 to March 2007. Cylindrical-conical plankton nets with $0.5-\mathrm{mm}$ mesh were equipped with a fluxometer that was attached to the opening of the net to record the volume of filtered water. Nets were placed along the sides of the boat. In sampling stations with lotic characteristics, the nets were submerged to approximately $10 \mathrm{~cm}$ and samples collected against the current for $10 \mathrm{~min}$. In lentic stations, the samples were collected at the same depth and exposure time, but the net was towed at a low speed.

Environmental variables, such as $\mathrm{pH}$, water temperature $\left({ }^{\circ} \mathrm{C}\right)$, electric conductivity $(\mu \mathrm{S} / \mathrm{cm})$ and dissolved oxygen $(\mathrm{mg} / \mathrm{l})$, were measured using portable devices during collection. In addition to these factors, information on fluviometric level and rainfall were provided by SUDERHSA (Superintendence of Water Resources Development and Environmental Sanitation) for the hydrometeorological station of Porto São José (PR).
Samples were preserved in $4 \%$ formalin buffered with calcium carbonate $\left(\mathrm{CaCO}_{3}\right)$. After collection, larval abundance was standardized to $10 \mathrm{~m}^{3}$ of filtered water according to Tanaka (1973) as altered by Nakatani et al. (2001).

The individuals were divided into larval and juvenile periods. The larval period was classified into four stages based on the degree of development and notochord flexion and caudal fin support elements according to Ahlstrom \& Ball (1954) and Kendall Jr. et al. (1984) and modified by Nakatani et al. (2001): 1) larval early stages (phase that starts with the hatching to the onset of exogenous feeding, with the opening of mouth, anus); 2) preflexion (from the beginning of the exogenous feeding to the beginning of the notochord flexion with the emergence of the caudal fin supporting elements); 3 ) flexion (from the notochord flexion through the formation of the caudal fin supporting elements to the beginning of pelvic fin formation); 4) postflexion (from the beginning of pelvic fin formation to the segmentation of ray fins, embryonic fin absorption and the emergence of scales). The juvenile periods is characterized by complete formation of the dorsal fins to the first gonadal maturation.

To determine whether the environmental variables and larval abundances were different among the sampling stations (Fig. 1), the data (environmental variables and larval

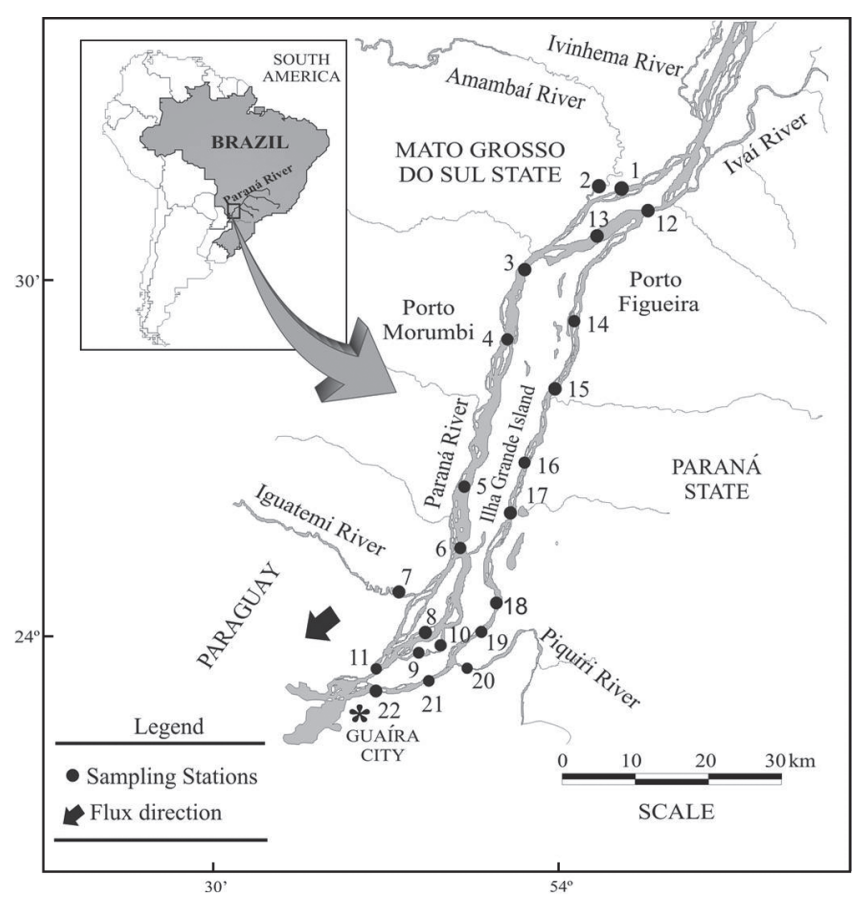

Fig. 1. Location of sampling stations (black dots). (1: Bandeirantes right channel; 2: Amambaí; 3: Triângulo; 4: Porto Santo Antônio; 5: Peruzzi; 6: Paraná/Iguatemi; 7: Iguatemi; 8: Paraná/Saraiva; 9: Saraiva middle; 10: Saraiva channel; 11: Ilha Grande right channel; 12: Bandeirantes left channel; 13: Ilha Grande Pontal; 14: Alvarenga; 15: Esmeralda; 16: Três Coqueiros; 17: São João; 18: Porto Luiz; 19 Porto Cerâmica; 20: Piquiri; 21: Porto Terra Roxa; 22: Ilha Grande left channel). 
abundances) were first log transformed $(\mathrm{x}+1)$ to linearize the relationship. To reduce the dimensionality (Peters, 1986), PCA was used to reduce the number of variables under consideration and to evaluate the ordination and possible differences between environmental variables. PCA axes were retained if they had eigenvalues greater than 1.0 in accordance with the Kaiser-Guttman criterion (Jackson, 1993). The sampling stations that were not recorded occurrences were excluded from analyses. Environmental variables that represented structural coefficients greater than 0.4 were considered as biologically important (Jackson, 1993). Analysis of variance (ANOVA) was applied to the retained PCA axes scores to evaluate whether significant differences occurred between environmental variables in the sampled environments. When the overall results were significant $(p<0,05)$ we applied the unequal N HSD (Honestly Significant Difference) to determine which sampling stations were different from the others. This same test was applied to examine the differences between larval densities, stations, stages, and sampling months.

The relationships between the environmental variables and larval densities for the developmental stages were examined using Pearson's correlation between PCA axes scores and the square root of larval densities.

The material analyzed in this study is deposited in the ichthyology collection of NUPELIA/UEM (Núcleo de Pesquisas em Limnologia Ictiologia e Aquicultura/ Universidade Estadual de Maringá), voucher number NUP 12020, NUP 12021, and NUP 12022.

\section{Results}

A total of 413 larvae were collected during sampling, and capture densities differed among the periods with the highest catch from the IV period (average density of 6.29 larvae/10 $\mathrm{m}^{3}$ ) followed by the III $\left(3.08\right.$ larvae/ $\left.10 \mathrm{~m}^{3}\right)$ (Fig. 2a). With respect to the monthly mean captures, January had the highest densities (1.85 larvae $\left./ 10 \mathrm{~m}^{3}\right)$, followed by March and February ( 0.71 and 0.26 larvae $/ 10 \mathrm{~m}^{3}$, respectively) (Fig. 2b). With respect to the spatial distribution, the stations located in lentic areas, such as Station 9 (Saraiva middle; 3.14 larvae $/ 10 \mathrm{~m}^{3}$ ) and Station 10 (Saraiva channel; 2.62 larvae $\left./ 10 \mathrm{~m}^{3}\right)$, had the highest abundance, followed by Station 2 (Amambaí; 1.15 larvae/10 $\mathrm{m}^{3}$ ), which was located in a lotic area (Fig. 2c).

With respect to monthly abundances by larval stage, larvae in early larval stages (VL) were captured in all six months and had their highest abundance in January with 0.25 larvae/10 $\mathrm{m}^{3}$. Larvae in the pre-flexion stage (PF) were captured in all months sampled and had more captures in March, with 1.89 larvae $/ 10 \mathrm{~m}^{3}$. Larvae in the flexion stage (FL) were present in all sampled months and had higher catches in January with 4.9 larvae $/ 10 \mathrm{~m}^{3}$. Larvae in the post-flexion stage (PF) and juvenile (JV) were present only in January with 2.67 , and 0.54 larvae $/ 10 \mathrm{~m}^{3}$, respectively (Fig. 3a).

Regarding captures per sampling stations, larvae in the early larval stage were frequent in 5 of the 22 stations, where the highest average catch occurred at Station 22 (Ilha Grande Left margin) with 0.23 larvae $/ 10 \mathrm{~m}^{3}$. The pre-flexion stage occurred in 18 stations and had its highest catch at Station 9 (Saraiva middle) with 1.35 larvae $/ 10 \mathrm{~m}^{3}$. The flexion stage had captures in 14 stations, and the highest catch was at Station 9 with 1.20 larvae $/ 10 \mathrm{~m}^{3}$. The post-flexion stage occurred in 6 stations and also had its highest abundance at station 9 (Saraiva middle) with 1.21 larvae $/ 10 \mathrm{~m}^{3}$. Finally, the juvenile stage occurred in 2 of the 22 stations and had its highest abundance at Station 2 (Amambaí) with 0.39 larvae/10 $\mathrm{m}^{3}$ (Fig. 3b).

The $\mathrm{pH}$ values ranged from 5.9 to 7.7 (Fig. 4a). Regarding electrical conductivity, the variation was from 44.0 to $64.6 \mu \mathrm{S} /$ $\mathrm{cm}$ (Fig. 4a). Water temperature values ranged between $24.5^{\circ} \mathrm{C}$ and $32.1^{\circ} \mathrm{C}$. Dissolved oxygen values were between 3.9 and $8.9 \mathrm{mg} / \mathrm{l}$ (Fig. 4b). Fluviometric levels oscillated between 245 and $637 \mathrm{~cm}$. Values of the rainfall ranged from $24.4 \mathrm{~mm}$ to 446.2 mm(Fig. 4c).

In the Principal Component Analysis, three axes were retained because they had eigenvalues higher than 1.0 (Axes 1,2 and 3 ). These axes explained $72.57 \%$ of the variation in the data. The first axis (Axis 1) had an eigenvalue of 1.81 and explained $30.16 \%$. The variables $\mathrm{pH}$, fluviometric level, and rainfall contributed the most to the Axis 1 , where $\mathrm{pH}$ had a negative eigenvalue fluviometric level and rainfall with positive eigenvalues. The second axis (Axis 2) had an eigenvalue of 1.46 and explained $24.45 \%$ of the variation, where dissolved oxygen, temperature and rainfall contributed the most to this axis; dissolved oxygen and rainfall had positive eigenvalues and temperature had a negative eigenvalue. The third factorial axis (Axis 3) explained $17.95 \%$ of the variation and had an eigenvalue of 1.07. Electrical conductivity contributed the most to this axis and had a positive eigenvalue (Table 1).

Through Pearson's correlation coefficient, we found that there was a correlation between the three PCA axes and the square root of larval density. In particular, the first axis corresponding to $\mathrm{pH}$, fluviometric level and rainfall was correlated with almost all of the developing stages, demonstrating a significant influence on larval capture. The second axis, formed mainly by oxygen, temperature, and rainfall, was correlated only with more advanced stages of development such as flexion, post-flexion and juvenile. The third axis was formed by electrical conductivity and was correlated with early larval stage, post-flexion and juvenile, demonstrating that conductivity had a role in these captures (Table 2).

Based on the ANOVA and HSD captures in the Saraiva middle station were significantly higher than those from other sampling stations $\left(\mathrm{F}_{(17,44)}=2,41 ; \mathrm{p}=0,01\right)$ (Fig. 5).

\section{Discussion}

Larvae were captured, especially in the early stage of development, in all sampled months and in different spawning periods, indicating elevated reproductive activity in January and March. Gomes et al. (2000) cited that the reproductive period and gonadal development peaks of $R$. quelen could 

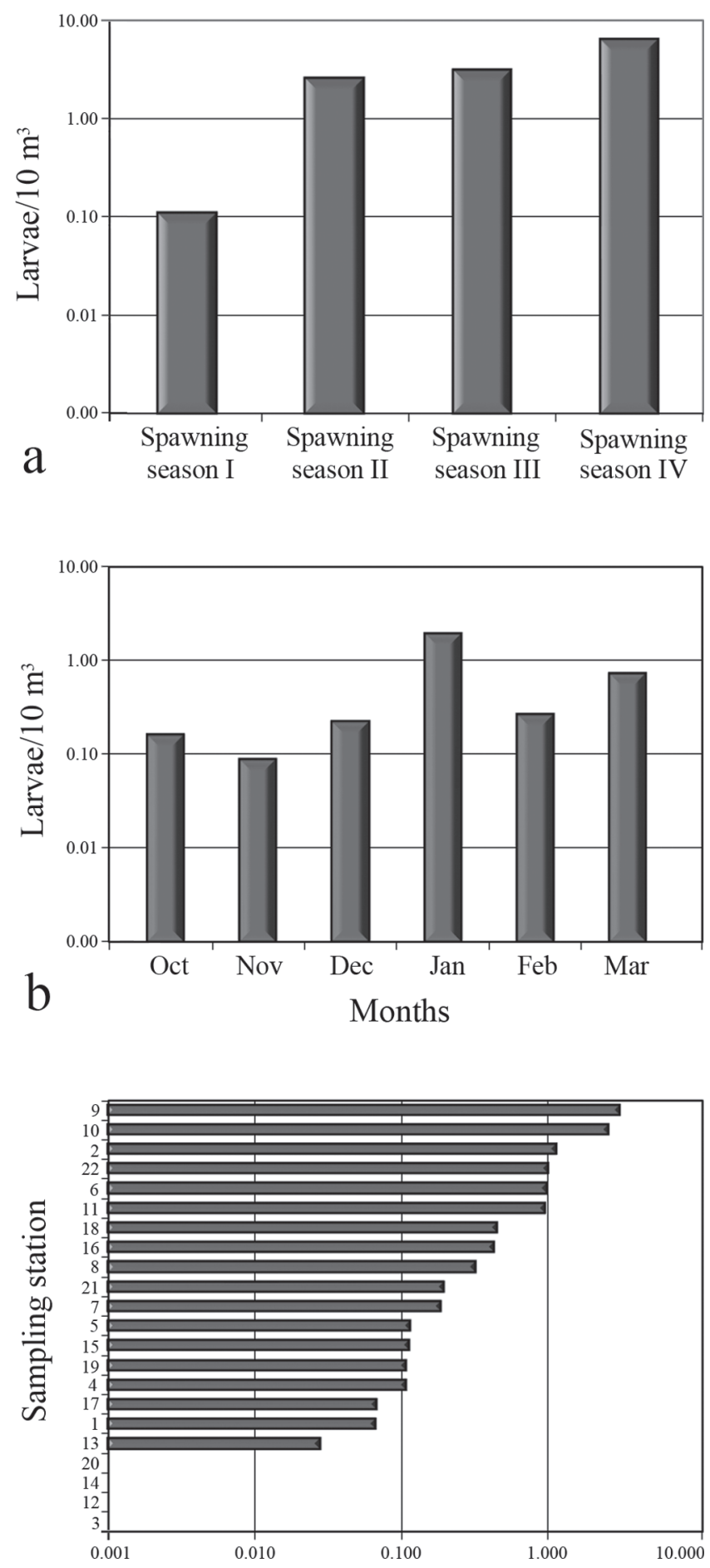

c

Larvae $/ 10 \mathrm{~m}^{3}$

Fig. 2. Average abundance of $R$. quelen larvae by spawning period (a), month (b), and sampling station (c).

vary each year and from one place to another. The authors cited a study by Bossemeyer (1976) on specimens from the Santa Maria region in Rio Grande do Sul State (southern Brazil), where the reproductive period was from August to February, and gonadal development peaked from August to September
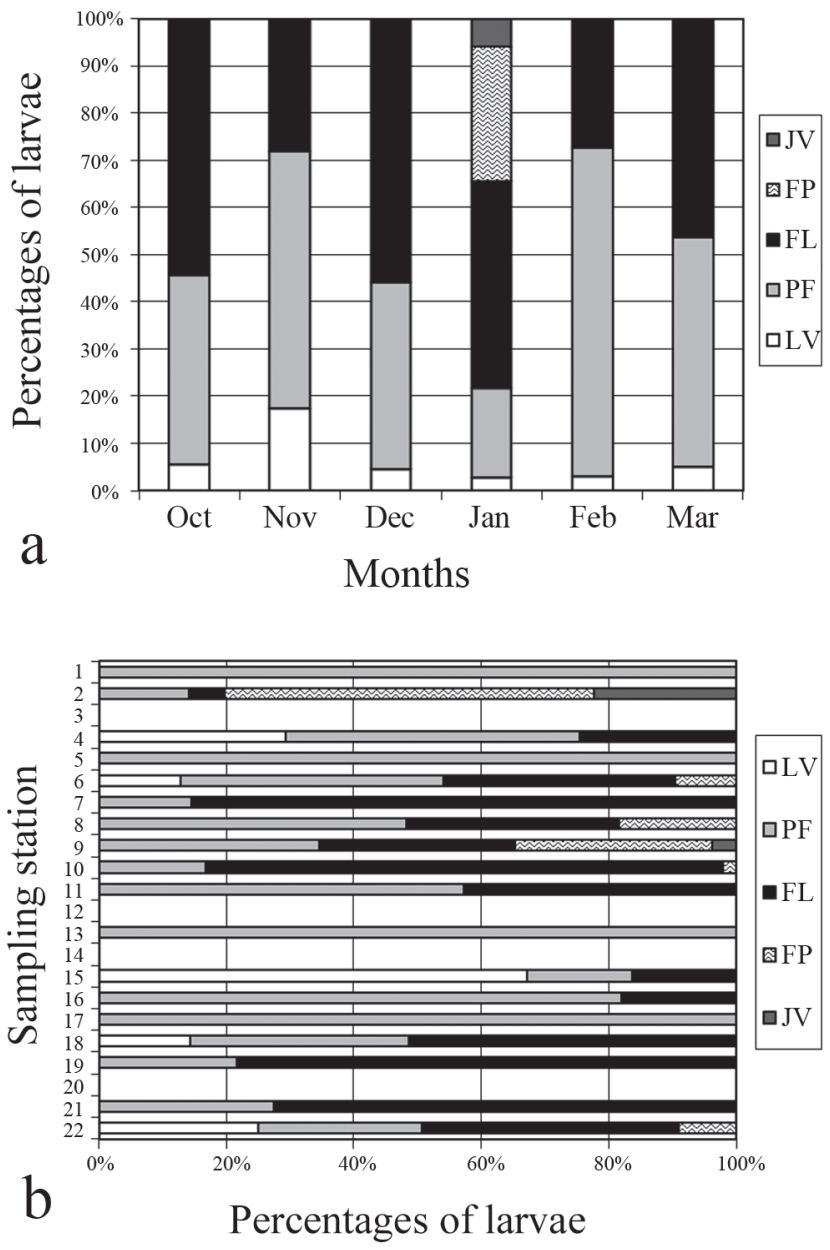

Fig. 3. Monthly density and per sampling stations of the larval development stages of Rhamdia quelen in Ilha Grande National Park.

and from January to February. Mardini et al. (1981) found breeding in advanced gonadal stages from September to May in Lagoa dos Quadros (RS), and Paula-Souza (1978) detected a higher gonadosomatic index from September to March in specimens from Paraná State. This prolonged reproductive period can be related to the fact that the species has parceled spawning (Godinho et al., 1978; Gomes et al., 2000; Pereira et al., 2006), which was apparent in our study from larvae captured in initial development stages (VL and PF) in all analyzed months.

The studied period of the year is characterized by high temperature values and rainfall and is considered the period of greatest reproductive activity of the fishes (Vazzoler, 1996). $R$. quelen larval abundance and their development stages were influenced not only by temperature and rainfall factors mentioned above, but by all analyzed environmental factors represented by the three PCA axes, demonstrating the close relationship between the species' reproduction and the environmental variables. Fish reproduction is a cyclic physiological process in which the periodicity patterns relate 

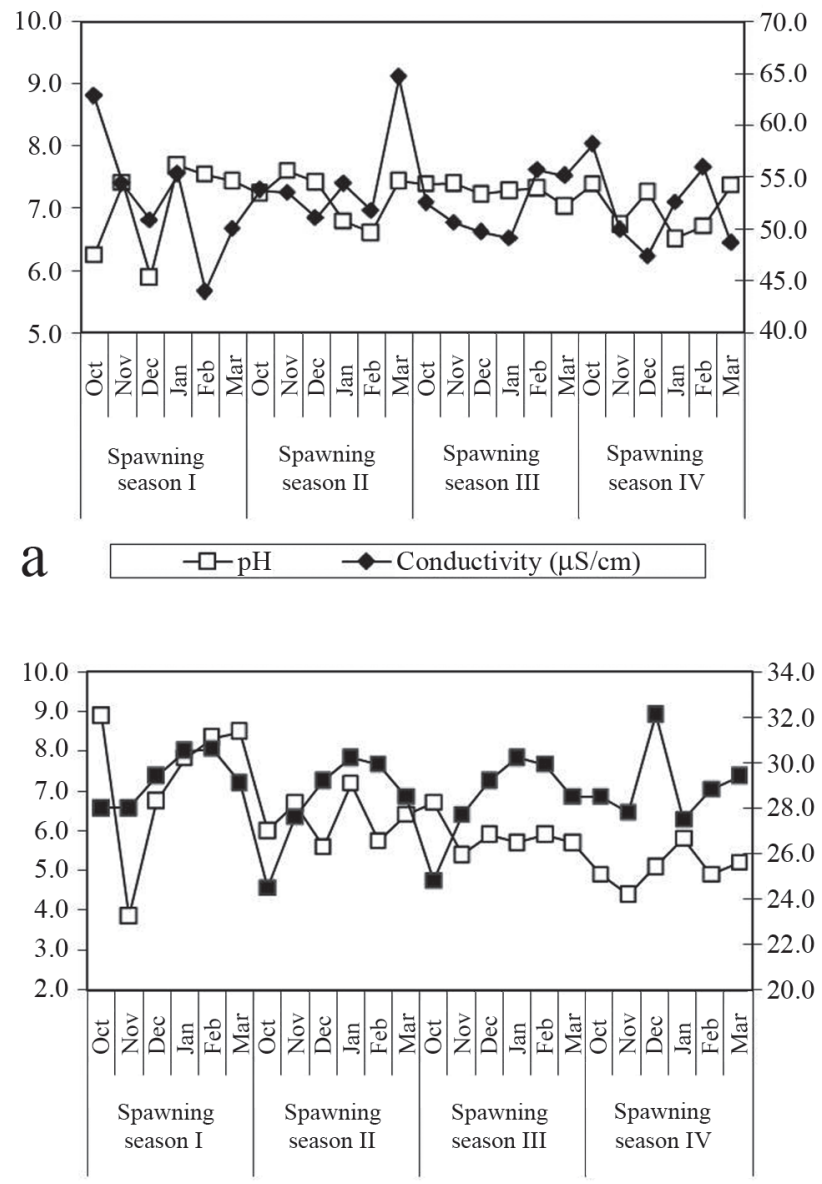

b $-\square-$ Dissolved Oxygen (mg/l) $\rightarrow-$ Temperature $\left({ }^{\circ} \mathrm{C}\right)$

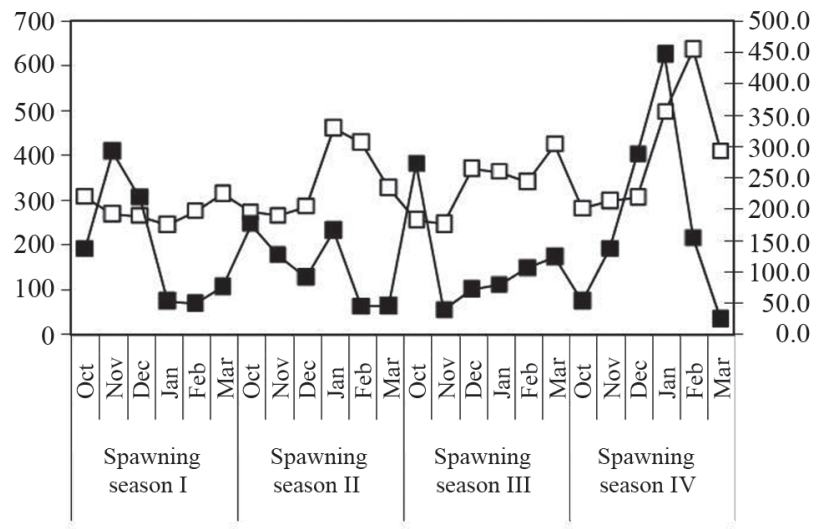

C $\quad-\square-$ Fluviometric level (m) $\rightarrow-$ Rainfall (mm)

Fig. 4. Monthly average values of environmental variables in different spawning periods in Ilha Grande National Park.

directly to environmental conditions to which individuals are exposed (Lowe-McConnel, 1987; Munro, 1990); thus, the environmental factors, especially temperature, rainfall, dissolved oxygen, electrical conductivity and fluviometric level, regulate reproduction (Vazzoler, 1996; Baumgartner et al., 2004; and Baumgartner et al., 2008).
An increase in photoperiod and temperature determine the beginning of gonad maturation in tropical fish. Photoperiod and temperature intensify during the reproductive period, and is a predictive trigger of spawning (Vazzoler, 1996). In relation to the PCA results, temperature negatively influenced larvae captures; that is, average catches were higher in months with lower temperatures. Nevertheless, it is important to note that monthly average temperatures during the four spawning seasons of the study were above $25^{\circ} \mathrm{C}$, and it was not a limiting factor in species reproduction. However, because Rhamdia quelen is a eurythermic species, it survives in a high range of temperatures (Chippari-Gomes, 1998). Campana et al. (1996) refer to temperature as a control factor of fish growth because it directly affects metabolic rates, oxygen consumption, feeding activity and digestibility. When temperatures are higher than the ideal range, fish reduce or even stop feeding (Frascá-Scorvo et al., 2001).

In addition to temperature and photoperiod, another factor that could explain the higher occurrence of $R$. quelen reproductive activity in January and March is the increase in precipitation, which substantially alters water physicalchemical conditions and causes spawning (Vazzoler, 1996). Captures from the tributaries, especially from Station 2 (Amambaí River), indicated that the species uses this environment as a breeding and spawning area, as demonstrated by the fact that larvae were captured in all stages of development in some parts of the river. A study by Nakatani et al. (2004); Baumgartner et al. (2004); Baumgartner et al. (2008), and Gogola et al. (2010) found that tributaries were important to fish reproduction in the floodplain of the upper Paraná River in a section just a few kilometers above the study area. The tributaries connect with the Paraná River on the right bank and are located in dam-free areas that are exclusively controlled by hydrologic cycles. Moreover, they contain several marginal lakes and extensive floodplains along their courses, offering favorable conditions for larvae spawning and growth.

It is unlikely that larvae captured in the stations on the main channel of the Paraná River are the result of spawning in the river. These captures probably result from spawning that occurred in the tributaries, where the eggs and larvae are passively transported by currents to the growth areas. Growth areas are usually marginal lakes, such as Saraiva Lake, where the greatest larval concentrations in several developmental stages were found. Because of the absence of newly hatched larvae (early larval stage), we were unable to determine whether the species uses this lake as a spawning area. Thus, this environment can be considered a place of development and feeding for $R$. quelen and other species. The characteristics of this lake, such as dense vegetal covering, reduced flow and an intermittent connection with the river, offer ideal conditions for the survival of the initial developmental phases. The importance of marginal lakes to fish reproduction was previously described by Nakatani et al. (1997) and Ziober et al. (2007), who considered these environments to be true nurseries for larvae that provide shelter and abundant food. 
Table 1. Structural coefficients obtained through principal component analysis for axes with eigenvalues greater than 1.0. Values greater than 0.4 were considered as biologically important.

\begin{tabular}{|c|c|c|c|c|c|c|c|}
\hline $\mathrm{pH}$ & Fluviometric level & Dissolved Oxygen & Temperature & Rainfall & Electrical Conductivity & Eingenvalue & $\%$ Explained variance \\
\hline Axis $1-0.615$ & 0.602 & -0.291 & 0.023 & 0.415 & -0.013 & 1.810 & 30.167 \\
\hline Axis $2-0.023$ & -0.069 & 0.522 & -0.673 & 0.477 & 0.201 & 1.467 & 24.453 \\
\hline Axis $3 \quad 0.291$ & 0.209 & -0.120 & 0.188 & 0.062 & 0.904 & 1.077 & 17.956 \\
\hline
\end{tabular}

Table 2. Pearson correlation coefficient between the square root of the density of Rhamdia quelen larvae by developmental stage and the scores of PCA axes in Ilha Grande National Park. Values in bold indicate significant correlations $(\mathrm{p}<0.05)$.

\begin{tabular}{lcccccc}
\hline & Root of larval density & Root of LV stage & Root of PF stage & Root of FL stage & Root of FP stage & Root of JV stage \\
\hline Axis 1 & 0.28 & 0.08 & 0.21 & 0.22 & 0.23 & 0.15 \\
Axis 2 & 0.16 & 0.04 & 0.07 & 0.14 & 0.19 & 0.15 \\
Axis 3 & 0.12 & -0.11 & 0.01 & 0.10 & 0.26 & 0.18 \\
\hline
\end{tabular}

The increase of capture abundances in the four studied stages suggests that $R$. quelen is finding conditions that are favorable to its reproduction. The increase in captures can generate questions regarding $R$. quelen reproductive activity, for instance, if the species is adapting or is influenced by environmental changes created by the Paraná River dam.

These questions may be answered by analyzing species reproductive strategies. Although there are controversies about whether $R$. quelen is a major migratory species or not, the results obtained in this study indicate that the species is a non-migrant or a migrant of short distances. This finding is consistent with Suzuki et al. (2004), who found that nonmigrant species are typically less affected by damming than the migrant ones because their spawning is not dependent on river floods. In studies by Conte (2008) in the same period and region of the present study, a similar pattern of capture was observed for species well known as non-migrants, such as Hypophthalmus edentatus (highwaterman catfish or mapará), Plagioscion squamosissimus (South American silver croaker or corvina), and Bryconamericus stramineus (piquira).

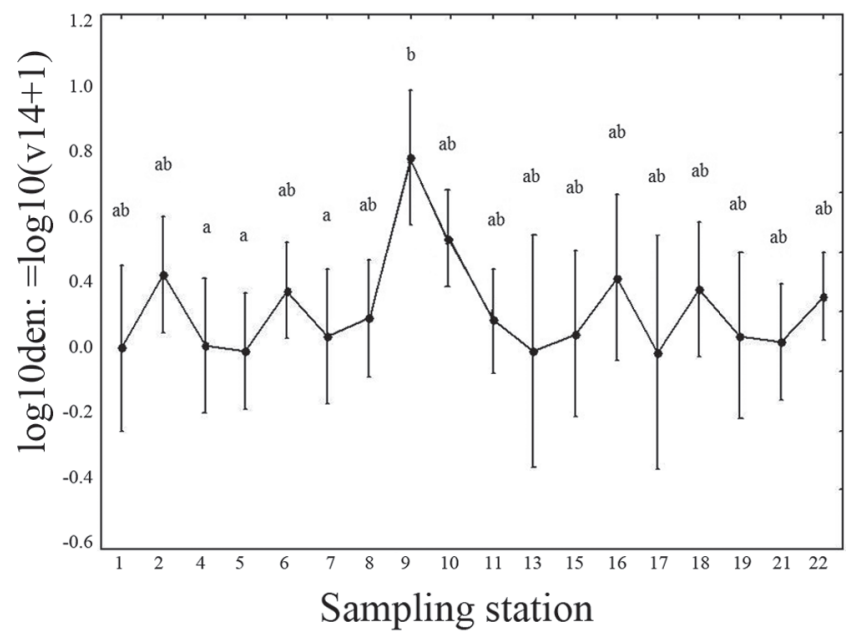

Fig. 5. Average and 95\% confidence interval for the mean $\log _{10}$ (Dens. +1 ) observed in the different sampling stations during the period (Different letters indicate significant differences according to the Unequal HSD test).
Thus, the flow control imposed on the Paraná River by dams does not appear to be exerting a major influence on R. quelen reproduction. However, additional studies are necessary for more conclusive results.

Based on the obtained data, we can verify the influence of environmental variables ( $\mathrm{pH}$, Fluviometric level, Dissolved oxygen, Temperature, Rainfall, Electrical conductivity) on reproduction, larval development and abundance of $R$. quelen and that it uses the tributaries, especially Amambaí River, as a place for spawning and development. Although there is no evidence of spawning in Saraiva Lake, it can be considered to be of major importance to larvae development, and consequently to the reproduction of the species, thus demonstrating the need to preserve these environments.

\section{Acknowledgements}

The authors acknowledge the financial support of Universidade Paranaense, the team of the Consórcio Intermunicipal para a Conservação do Remanescente das Várzeas do Rio Paraná e Áreas de Influência (CORIPA) and the Instituto Ambiental do Paraná (IAP) for supporting the collections.

\section{Literature Cited}

Agostinho, A. A., L. C. Gomes \& F. M. Pelicice. 2007. Ecologia e Manejo de Recursos Pesqueiros em Reservatórios do Brasil. Maringá, 501p. Agostinho, A. A., S. M. Thomaz \& L. C. Gomes. 2004b. Threats for biodiversity in the floodplain of upper Paraná River: effects of hydrological regulation by dams. Ecohydrology and Hydrobiology, 4(3): 255-268.

Agostinho, A. A., S. M. Thomaz, C. V. Minte-Vera \& K. O. Winemiller. 2000. Biodiversity in the high Paraná River floodplain. Pp. 89-118. In: Gopal, B., W. J. Junk, J. A. Davis (Ed.). Biodiversity in wetlands: assessment, function and conservation. Leiden, The Netherlands: Backhuys Publishers.

Agostinho, A. A., Vazzoler, A. E. A. M. \& S. M. Thomaz. 1995. The high river Paraná basin: limnological and ichthyological aspects. Pp. 59-103. In: Limnology in Brazil, Tundisi, J. G., C. E. M. Bicudo \& T. Matsumura-Tudinsi. Rio de Janeiro: ABC/SBL, 376p. 
Ahlstrom, E. H. \& O. P. Ball. 1954. Description of eggs and larvae of jack mackerel (Trachurus symmetricus) and distribution and abundance of larvae in 1950 and 1951. Fishery Bulletin, Washington, DC, 56: 209-245.

Baumgartner, G., K. Nakatani, L. C. Gomes, A. Bialetzki, P. V. Sanches \& M. C. Makrakis. 2004. Identification of spawning sites and natural nuseries of fishes in the upper Paraná River, Brasil. Environmental Biology of Fishes, 71: 115-125.

Baumgartner, G., K. Nakatani, L. C. Gomes, A. Bialetzki, P. V. Sanches \& M. C. Makrakis. 2008. Fish larvae from the upper Paraná River: do abiotic factors affect larval density? Neotropical Ichthyology, 6(4): 551-558.

Bossemeyer, I. M. K. 1976. Mudanças morfológicas no ovário de Rhamdia sapo (Pimelodidae) relacionadas com o ciclo reprodutivo. Unpublished Ph.D. Dissertation. Universidade Federal de Santa Maria, Santa Maria, 48p.

Campana, S. E., R. K. Mohn, S. J. Smith \& G. A. Chouinard. 1996. Reply: Spatial implications of a temperature-based growth model for Atlantic cod (Gadus morhua) off the eastern coast of Canada. Canadian Journal of Fisheries and Aquatic Sciences, 53: 2912-2914.

Carneiro, P. C., J. D. Mikos, M. Schorer, P. R. C. O. Filho \& F. Bendhack. 2003. Live and formulated diet evaluation through initial growth and survival of jundiá larvae, Rhamdia quelen. Scientia Agrícola, 60(4): 615-619.

Chippari-Gomes, A. R. 1998. Temperaturas letais de larvas e alevinos de jundiá, Rhamdia quelen (Quoy e Gaimard, 1924 - Pisces, Pimelodidade). Unpublished Ph.D. Dissertation. Universidade Federal de Santa Maria, Santa Maria, 99p.

Conte, R. B. 2008. Monitoramento do ictioplâncton na região do Parque Nacional de Ilha Grande - alto Rio Paraná. Unpublished Ph.D. Dissertation. Universidade Paranaense. Umuarama, 50p.

Coripa. 2003. Zoneamento ecológico-econômico (ZEE) das APA'S Intermunicipais de Ilha Grande - PR. Altônia, CD-ROOM.

Frascá-Scorvo, C. M. D., D. J. Carneiro \& E. B. Malheiros. 2001. Comportamento alimentar do matrinxã (Brycon cephalus) no período de temperaturas mais baixas. Boletim do Instituto de Pesca, São Paulo, 27(1): 1-5.

Godinho, H. M., M. A. Basile-Martins, N. Fenerich \& M. Y. Narahara.1978. Desenvolvimento embrionário e larval de Rhamdia hilarii (Valenciennes, 1840) (Siluriformes, Pimelodidae). Revista Brasileira de Biologia, 38(10): 151-156.

Gogola, T. M., V. S. Daga, P. R. L. Silva, P. V. Sanches, E. A. Gubiani, G. Baumgartner \& R. L. Delariva. 2010. Spatial and temporal distribution patterns of ichthyoplankton in a region affected by water regulation by dams. Neotropical Ichthyology, 8(2): 341-349.

Gomes, L. C., J. I. Golombieski, A. R. C. Gomes \& B. Baldisserotto. 2000. Biologia do jundiá Rhamdia quelen (Teleostei, Pimelodidae). Ciência Rural, 27(2): 179-185.

Guedes, D. S. 1980. Contribuição ao estudo da sistemática e alimentação de jundiás (Rhamdia spp) na região central do Rio Grande do Sul (Pisces, Pimelodidae). Unpublished Ph.D. Dissertation. Universidade Federal de Santa Maria, Santa Maria, 99p.

Ibama. 2007. Estatísticas da pesca 2005 - Brasil, grandes regiões e unidades da Federação. Brasília, 147p.

Jackson, D. A. 1993. Stopping rules in principal components analysis: A comparison of heuristical and statistical approaches. Ecology, 74: 2204-2214.

Kendall, Jr., A. W., E. H. Ahlstrom \& H. G. Moser. 1984. Early life history stages of fishes and their characters. Pp. 11-22. In: Moser, H. G., W. J. Richards, D. M. Cohen, M. P. Fahay, A. W. Kendall, Jr. \& S. L. Richardson. Ontogeny and systematics of fishes: based on International Symposium dedicated to the memory of Elbert Halvor Ahlstrom. Lawrence: American Society of Inchthyologists and Herpetologists, 778p.

Lowe-McConnel, R. H. 1987. Ecological studies in tropical fish communities. Cambridge: Cambridge University Press, 382p.

Mardini, C. V., M. A. Silveira \& D. H. L. Barenho. 1981. Técnica de indução da desova em jundiá (Rhamdia quelen) empregada na estação experimental de piscicultura da Lagoa dos Quadros. Porto Alegre: Secretaria da Agricultura, 4: 14p.

Munro, A. D. 1990. General introduction. Pp. 1-11. In: Scott, A. P. \& T. J. Lam. Reproductive seasonality in teleosts: Environmental influencies. Boca Raton: CRS Press, 254p.

Nakatani, K., A. A. Agostinho, G. Baumgartner, A. Bialetzki, P. V. Sanches, M. C. Makrakis \& C. S. Pavanelli. 2001. Ovos e larvas de peixes de água doce: Desenvolvimento e manual de identificação. Maringá, Eduem, 379p.

Nakatani, K., G. Baumgartner \& M. Cavicchioli. 1997. Ecologia e ovos e larvas de peixes. Pp. 218-306. In: Vazzoler, A. E. A. M., A. A. Agostinho \& N. S. Hahn. A planície de inundação do alto rio Paraná: aspectos físicos, biológicos e sócio econômicos. Maringá, Eduem, 460p.

Nakatani, K., A. Bialetzki \& P. V. Sanches. 2004. Eggs and larvae of fishes in the Upper Paraná River Floodplain. Pp. 157-161. In: Agostinho, A. A., S. M. Thomaz \& L. Rodrigues (Org.). Structure and functioning of the Paraná River and its floodplain. Maringá, Eduem, 1: 275p.

Paula-Souza, G. 1978. Reprodução de Rhamdia branneri, 1911 (Pisces, Siluriformes) e suas relações com fatores abióticos. Unpublished Ph.D. Dissertation. Universidade Federal do Paraná, Curitiba, 66p.

Pereira, C. R., L. J. G. Barcellos, L. C. Kreutz, R. M. Quevedo, F. Ritter \& L. B. Silva. 2006. Embryonic and larval development of jundiá (Rhamdia quelen, Quoy \& Gaimard, 1824, Pisces, Teleostei), a South American catfish. Brazilian Journal of Biology, 66(4): 1057-1063.

Peters, R. K. 1986. The role of prediction of limnology. Limnology and Oceanography, 31: 1143-1159.

Sanches, P. V., K. Nakatani, A. Bialetzki, L. C. G. Baumgartner \& E. A. Luiz. 2006. Flow regulation dams affecting ichthyoplankton: the case of Porto Primavera dam, Paraná River, Brasil. River Research and Applications, 22(5): 555-565.

Suzuki, H., F. M. Pelicice, E. A. Luiz, J. D. Latini \& A. A. Agostinho. 2004. Reproductive strategies of the fishes comunity of the upper Paraná River floodplain. In: Agostinho, A. A., L. Rodrigues, L. C. Gomes, S. M. Thomaz \& L. E. Miranda. Structure and functioning of the Paraná River and its floodplain: LTER - site 6 - (PELD site 6). Maringá, Eduem, 275p.

Tanaka, S. 1973. Stock assessment by means of ichthyoplankton surveys. FAO Fisheries Technical Paper, 122: 33-51.

Vazzoler, A. E. A. 1996. Biologia da reprodução de peixes teleósteos teoria e prática. Maringá, Eduem, 163p.

Zaniboni-Filho, E. \& U. H. Schulz. 2004. Migratory fishes of the Uruguay River. Pp. 135-168. In: Carolsfeld, J., B. Harvey, A. Baer \& C. Ross. Migratory fishes of the South America: biology, social importance and conservation status. IDRC/World Bank/ World Fisheries Trust, Canada, 372p.

Ziober, S. R., A. Bialetzki, L. C. Gomes \& D. Kipper. 2007. The importance of a marginal lagoon as a fish nursery in the upper Paraná River floodplain. Acta Limnologica Brasiliensis. Botucatu, 19: 369-381.

Accepted January 23, 2011 Published June 30, 2011 